Revue Française de Civilisation Britannique

\title{
Better Together and the No Campaign: from Project Fear to Grace?
}

Better Together et la campagne pour le 'non'

\section{Fiona Simpkins}

\section{(2) OpenEdition \\ Journals}

Electronic version

URL: http://journals.openedition.org/rfcb/418

DOI: $10.4000 / \mathrm{rfcb} .418$

ISSN: 2429-4373

Publisher

CRECIB - Centre de recherche et d'études en civilisation britannique

Electronic reference

Fiona Simpkins, « Better Together and the No Campaign: from Project Fear to Grace? », Revue

Française de Civilisation Britannique [Online], XX-2 | 2015, Online since 23 July 2015, connection on 19

April 2019. URL : http://journals.openedition.org/rfcb/418 ; DOI : 10.4000/rfcb.418

This text was automatically generated on 19 April 2019.

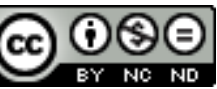

Revue française de civilisation britannique est mis à disposition selon les termes de la licence Creative Commons Attribution - Pas d'Utilisation Commerciale - Pas de Modification 4.0 International. 


\title{
Better Together and the No Campaign: from Project Fear to Grace?
}

\author{
Better Together et la campagne pour le 'non'
}

\author{
Fiona Simpkins
}

1 The major cross-party No campaign, Better Together, was launched a month after Yes Scotland, on $25^{\text {th }}$ June 2012, at Edinburgh's Napier University by former Chancellor of the Exchequer, Alistair Darling. Although the name chosen for the campaign, Better Together, deliberately omitted the terms Union or unionist and sounded positive and respectful of both unionists and nationalists alike, its message generally failed to meet the target that its name initially suggested. We shall see that the campaign, based on the idea of getting the best out of both worlds - by enjoying the benefits of devolution as well as a union with the rest of the UK - or of the referendum debate being about "what unites us, not about what divides us" as Alistair Darling announced in his inauguration speech of the Better Together campaign in June 2012, soon showed more signs of division than unity while its tone became increasingly negative. In fact, the debate was dragged into bitter disputes over the financial risks entailed by independence, the looming spectre of recession, the loss of Scotland's EU membership and other cataclysmic-like scenarios to name but a few. One of the reasons for this turn of events was the length of the campaign, which, if the long campaign preceding the 16-week official campaign is taken into account, represents the longest electoral campaign in modern British political history. Another rests with the composition and nature of the No campaign itself. Faced with an increasingly successful nationalist party in Scotland which could boast of being the first Scottish party in terms of electoral support and of representing Scotland's interests rather than UK-wide interests like the three main British parties campaigning for Better Together, the No campaign was naturally entrenched in a defensive position whilst the SNP played the role of challenger. Furthermore, it represented the common effort of three otherwise unlikely-minded British parties to work together and publicly collaborate to safeguard the Union. The difficulties that this collaboration represents were immense 
in that the three participating parties had distinct electoral and political histories in Scotland and each faced inner divisions and distinct challenges which this paper seeks to examine.

\section{Organisation, action and finance of the Better Together campaign}

2 Better Together was established as the official umbrella organisation of the No campaign. It was created as a cross-party body which would gather the three pro-union parties (Labour, the Conservatives and the Liberal-Democrats) as well as all those not affiliated to a political party, and which would be run by a cross-party Board of Directors. The Board included five members and somewhat represented the electoral strengths of the three parties in that three of its members were Labour (including its chairman, Alistair Darling), one was a Conservative and the last a Liberal Democrat. Together with Darling, the Board thus included Labour MSPs Jackie Baillie and Richard Baker, the late Conservative MSP David McLetchie (1952-2013), and Craig Harrow, convener of the Scottish Liberal Democrats. The strategic mastermind of Better Together, however, would be its Campaign Director, Blair McDougall, a high profile Labour political advisor who ran David Miliband's campaign for the Labour Party leadership in 2010. He also worked as an advisor to Jim Murphy's successful Scottish Labour Party leadership election bid. Other full time employees of the campaign included a Director of Communications (Rob Shorthouse), a Press Officer (David Ross), a Policy and Strategy Adviser (Jim Gallagher who previously served as secretary to the Calman commission), as well as a Research and Engagement Officer (Gordon Aikman), a National Campaign Organiser (Rob Murray) and Local Campaign Organisers. The team were in charge of formulating the campaign's slogans and messages, which were previously tested through focus groups, developing network channels through which information could be conveyed, mobilising volunteers as well as training and briefing them on media management, doorstep canvassing and voter pools targeting, and finally organising events, social media activities and meetings throughout the country. ${ }^{1}$ The structure offered by the Better Together campaign was thus much more centralised and its grasp over both the message content and the means of communication used by activists more extensive than the Yes campaign which allowed its activists and sub-campaigning groups more leeway and spontaneity. ${ }^{2}$

Using the model set up by the Yes Scotland campaign, Better Together also created interest groups such as Rural Better Together (launched at the 2013 Royal Highland Show), Forces Together (awkwardly launched by Alistair Darling at the Scottish Conservative conference) or Academics Together. The idea behind those subgroups was for their members to call people with similar professional activities in order to identify undecided voters before trying to convince them of voting no. Other subgroups were created based on locality such as Better Together Airdrie and Better Together Crieff, or even both interests and locality with Better Together Aberdeen Youth and Students for instance.

4 Better Together also launched a new initiative to target undecided voters in the summer of 2013 with the Blether Together campaign. This initiative was the product of Better Together's appointment of Blue State Digital, the agency that worked on the successful first election campaign for US President Obama. The recruitment drive using social media 
and YouTube was launched in an attempt at recruiting volunteers who were given the personal details of members of the public and asked to cold-call them in order to canvass them for support. All information gleaned by the calls was stored in the campaign database and transmitted to the three parties involved in Better Together. This initiative followed a rather controversial one launched in April 2013 of unsolicited text messages and although its beginnings were similarly surrounded with controversy due to the fact that people's personal details and information were at risk of being disclosed to outside organisations, the Blether Together campaign became rather successful in terms of volunteer recruitment (more than 3,500 volunteers signed up). Finally, the creditchecking group Experian was also hired by Better Together to devise a new data management tool. The Patriot software database stored all consumer data obtained from lenders and companies who voters have contracts with and allowed Better Together to identify lifestyle indicators, categorise voters and link them with activists of a similar age or with similar social media friends in order to improve voter targeting and canvassing.

Third party endorsements also featured highly in the Better Together campaign as it was initially somewhat more successful than its rival at recruiting high-profile non politicians to support its cause. The SNP had made much of third party endorsements during its successful May 2011 Scottish Parliament election campaign and Better Together aimed at following this model and mobilising as much support as possible in order to break away from an all political image. It thus put forward the support of several sportsmen such as Gavin Hastings, Alex McLeish, Chris Hoy and Alex Fergusson, as well as musicians, writers and actors including Sharleen Spiteri, J.K. Rowling, Ewan McGregor and Billy Connolly. Their support featured prominently in social media such as Twitter and Facebook, which a March 2014 study from the University of Strathclyde shows were equally used by both the Better Together and Yes Scotland campaigns. ${ }^{3}$ Although the study shows that the Yes Scotland campaign got more support on online social media, its authors linked this to the age groups social media users generally belong to. ${ }^{4}$ In any case, social media did play an important role in local campaigning especially as it enabled Better Together to mobilise more volunteers and disseminate information.

6 In fact, much of the No campaign focused on local campaigning and relied primarily on community-based activities. It was felt that identifying potential sympathisers or undecided voters and using traditional campaigning methods such as canvassing, leafleting and organising meetings would be much more efficient on a local basis. National media channels were of course used to formulate a wider message and reach the electorate as a whole but the focus of the campaign as we have seen was on targeting voters and putting them in contact with trusted local figures, like local council members for instance, who would be better able to get the message across. The No campaign furthermore felt less pressure than its opponent in convincing the press and media as a whole as the latter were generally more sympathetic to their cause, with the Sunday Herald being the only Scottish newspaper to support a Yes vote. As a matter of fact, the BBC itself was repeatedly accused of being biased towards the Better Together campaign. ${ }^{5}$

7 The Better Together campaign was also well-funded although finance was a particular source of tensions during the campaign. The Electoral Commission published its decision on spending limits in January 2013 and allowed both the Yes Scotland and the Better Together campaigns to spend $£ 1,500,000$ each during the official campaign, which is equivalent to the spending limits enjoyed by each of Scotland's main political parties during Scottish Parliament election campaigns. Furthermore, political parties 
represented in the Scottish Parliament were each allowed to spend amounts relative to their political strengths during the official 16-week campaigning period preceding the referendum (Labour was given a $£ 834,000$ limit, the Conservative party $£ 396,000$, and the Liberal Democrats $£ 201,000$ ). Parties could spend as much as they wished prior to the start of the formal campaign. The main source of controversy rested with the origin of donations and the disclosure of the list of donors to each party. By April 2013, three of the four largest donors of the Better Together campaign drew heavy criticism from the Yes campaign as they were all located outside Scotland (Douglas Flint, former chairman of HSBC Holdings, Ian Taylor, chief executive of Vitol, and crime writer C.J. Sansom). ${ }^{6}$ The $£ 500,000$ donation by Scottish oil trader, Ian Taylor, was particularly controversial due to his links with a Serbian paramilitary leader suspected of war crimes on the one hand and tax avoidance behaviour in the UK on the other. Although the No campaign was repeatedly urged by the Yes camp as well as former Labour First Minister Henry McLeish and former Liberal Democrat leader Lord Ashdown to return the donation, Better Together declined and put pressure instead on Yes Scotland to release its own list of donors, which it did in April 2013.

8 One usual source of funding for Labour-led campaigns was remarkably absent from the 2014 independence referendum campaign however as the unions gave little support to the No campaign. In fact, only the GMB - traditionally seen as more centrist and the smallest of Scotland's three main unions - agreed to support Labour during the campaign. The other two unions, Unite and Unison, traditionally more to the left, refused to endorse either campaign in the months leading to the independence referendum. Unison stressed that the union did "not have a policy position, either way". Its official line as stated on its website on $2^{\text {nd }}$ July 2014 was the following: "We continue to scrutinise the positions of the various campaigns and would urge all sides to explain to our members how they intend to go about creating a more just, fairer society in Scotland. Any constitutional change should be a means to that end and not an objective in itself". ${ }^{7}$ It thus suggested that neither side of the debate had given sufficient guarantees or convincing arguments on the issues which were of prime importance to the unions' work. Similarly, Unite conducted an extensive consultation of its members before its Scottish committee, the key decision-making body in the union, stated on $18^{\text {th }}$ March 2014 that it would neither give a recommendation to its members nor endorse a campaign prior to the independence referendum. Clearly, one of the reasons for this decision was to avoid any long-lasting divisions within the ranks of the unions' members over an issue which did not directly affect its main raison d'être, as suggested by the following declaration by Unite:

[I]rrespective of September's outcome, Unite will continue to fight for the issues important to our members - jobs, wages, public services, the welfare state, tackling inequality, and better employment and trade union rights - but constitutional changes whether it is independence or greater devolution will mean different things to different people based on their industrial, social or personal circumstances. $^{8}$

\section{The spin-offs: a symptom of strained relationships and distinct challenges}

9 In fact, another sticking point for the unions was the awkward presence of the Conservative party in the Better Together campaign. This was clearly expressed by Dave 
Watson" of Unison in May 2013 when he declared: "While I appreciate the referendum campaign has to have a formal Yes and No campaign, most of us in the Labour movement have a huge difficulty with any campaign that includes the Tories". ${ }^{10}$ Notwithstanding the fact that the Labour party's Scottish Executive was not consulted in advance about the creation of Better Together, many within the Scottish Labour party as well as the unions feared that this close collaboration with the Conservatives might be toxic to Labour's electoral fortunes and come back to haunt the party at the next elections of 2015 and 2016. These views are to a large degree responsible for the setting up of another vehicle for the No campaign, United with Labour, this time with the agreement of the Scottish Executive. The campaign was launched in May 2013 by Scottish Labour Party leader, Johann Lamont as well as deputy leader Anas Sarwar and former Prime Minister Gordon Brown. It was to enable Labour activists, local branches (CLPs) and trade unionists who felt uncomfortable in the cross-party campaign to deliver a distinctly Labour message in favour of the union and organise grassroots campaigning in areas where Labour was traditionally well established, especially in the west central belt, where it was believed that a singular Labour campaign might come across better than Better Together. Gordon Brown was asked to head the campaign and Anas Sarwar was responsible for liaising between the two campaigns and the Scottish Labour Party Executive. Both campaigns worked hand in hand and complemented one another as United with Labour tended to focus on grassroots campaigning in traditional Labour bastions while Better Together delivered its message on a wider scale through the media.

Scottish Labour also set up its own Devolution Commission charged with examining the current state of devolution and determining what new powers should be devolved to the Scottish Parliament. It was composed of three MSPs (Scottish party leader Johann Lamont, Sarah Boyack and Duncan McNeil), three MPs (deputy leader Anas Sarwar, Shadow Secretary of State for Scotland Margaret Curran and Shadow Minister for Work and Pensions Gregg McClymont), one MEP (Catherine Stihler), as well as representatives of local government, trade unions and CLPs. Its final report, published in March 2014 was meant to frame its view of the constitutional settlement in Scotland after the independence referendum and of the kind of society Labour envisioned in Scotland. Indeed, the length of the campaign preceding the referendum meant that the debate quickly widened to the "larger social vision"11 both camps had of Scotland. Rather than focusing on the constitutional intricacies of independence, all parties sought to differentiate themselves from their political opponents by defining their vision of a postreferendum Scottish society. This would be particularly the case of the Scottish Labour party whose social aspirations and ideals are broadly similar to those of the SNP, in contrast with the clear differences that separates both parties from the Conservative party for instance, notably in terms of governance of the welfare state. The debate therefore shifted to which constitutional settlement would better preserve these social ideals against what is widely accepted in Scotland as the Conservative party's relentless attacks. The focus thus turned to issues such as pensions, which Labour argued would be better protected if Scotland rejected independence, or attacks on Alex Salmond's proposal to abolish the Corporation Tax, which Labour warned would reduce tax revenues in Scotland and negatively impact the country's public services. The March 2014 report of Labour's Devolution Commission was thus considered as a means to defend the idea that Scotland's social democratic values would be best advanced within the union with fresh powers devolved to the Scottish Parliament, as expressed by the document: 
In this union we pool and share resources to ensure hard-working people, pensioners and those in need have equal economic, social and political rights throughout the entire UK. This is an idea - founded on solidarity, community and fairness - that is much greater than any notion of creating an independent state. ${ }^{12}$

11 The proposals included in the report were in fact rather limited and watered down compared to the interim report of April 2013 which considered full devolution of income tax. In the end, it promised to set Scottish rates of income tax, including higher rates for high earners of at least 50p in the pound, block cuts in business taxes and increase spending on housing together with devolving the responsibility for housing benefits. The report also foresaw the devolution of Scotland's only rail franchise as a mutualised "not for profit" organisation and more powers devolved to local authorities and community organisations. Paradoxically, it was in terms of welfare that the Labour Devolution Commission was least inclined to decentralise responsibilities, arguing that the welfare system was better protected by the pooling of UK resources whilst exposing itself to heavy criticism that it was precisely in the union that it suffered from reforms imposed by Westminster.

The Scottish Labour party, however, was not the only participant in the Better Together campaign to set up its own campaign and define its singular vision of post-referendum Scotland. The Conservatives too launched their own "Conservative Friends of the Union" initiative at their spring conference of March 2012, which was led by Scottish Conservative Party leader Ruth Davidson and then UK Conservative co-chairwoman Baroness Warsi, as well as the party's leader in the Lords, Lord Strathclyde, the then Welsh Secretary Cheryl Gillian and former First Minister of Northern Ireland Lord Trimble. With only one MP in Scotland (David Mundell), the campaign was an unexpected success as the Conservatives were pleasantly surprised to receive almost $£ 150,000$ in small donations from 50,000 people within months of its creation. The poor results of the Scottish Conservative party at the 2010 and 2011 elections (winning only one seat at Westminster and fifteen in Holyrood) meant that that the party fully realised its limits in Scotland, was quite content to stay at the back of the scene within the Better Together campaign and let Labour take the lead. This does not mean that the Conservatives' involvement was half-hearted. In fact, the Scottish party was quite enthusiastic about the referendum campaign as it saw it as a unique opportunity to boost its profile and rebuild support in Scotland. The late Conservative MP David McLetchie was active in the Better Together campaign and Annabel Goldie and Ruth Davidson were both present at its launch in Edinburgh's Napier University. More than anything, the referendum campaign gave Scottish Conservatives the opportunity to rethink their position over Scotland's constitutional future.

13 The constitutional debate within the Scottish Conservative Party was first raised by the Scottish Conservative leadership campaign which followed the poor results of the Conservatives in May 2011 (the party won 15 seats with $11.63 \%$ of the vote) and the acknowledgement of a widespread perception that emerged in Scotland in the late 1970s that the Conservative party is anti-Scottish. One of the main contestants, Murdo Fraser, was the first to claim that the party had to "see the referendum on independence not as a threat, but as an opportunity"13 as he launched his leadership bid. Fraser admitted that: "early opposition to the Scottish Parliament has led us to being portrayed as anti-Scottish [and] that is still the perception of much of the Scottish electorate". He thus proposed that in order "to counter it, we need both an admission and a reality check" and that the party should move away from the slippery slope argument that held that devolution 
would gradually lead to independence and which it had clung to since 1979. He suggested that a "new Unionism would provide financial devolution to the Scottish Parliament". However, the other main contestant in the leadership bid, Ruth Davidson, initially adopted a contrary view as she claimed that there would be "no half-way house, no second question - no march to fiscal autonomy. When the referendum is done, and Scotland in the Union has won the day, let that be an end to it" ${ }^{14}$ Narrowly elected as leader, she would soon be forced to change her mind by Prime Minister David Cameron's own admission in a February 2012 speech that "[ $t]$ his does not have to be the end of the road. When the referendum on independence is over, I am open to looking at how the devolved settlement can be improved further". ${ }^{15}$

14 The Conservative-led Coalition government's strategy was to accept the organisation of a referendum, which was now unavoidable, on terms it found acceptable and to avoid appearing anti-Scottish in a bid to save the union. The new Scottish Conservative leader thus operated a complete U-turn and came round to the view initially expressed by Fraser. In March 2013, she conceded that "a parliament with little responsibility for raising the money it spends will never be properly accountable to the people of Scotland. [...] So that means in future a far greater share of the money spent by the Scottish Parliament should be raised by it". ${ }^{16} \mathrm{~A}$ working group was set up to "examine specifically the question of strengthening devolution and the accountability of the Scottish Parliament by examining its structures and extending its powers over taxation". It would be chaired by Lord Strathclyde and include former Scottish Conservative leader Annabel Goldie, former Presiding officer Alex Fergusson as well as constitutional experts Alan Trench and Adam Tomkins. The Commission on the Future Governance of Scotland published its report ${ }^{17}$ in May 2014 and shared some similarities with the report published by Labour's own Devolution Commission. Indeed, the Conservative commission also suggested that the Scottish Parliament should become responsible for setting rates and bands of income tax throughout Scotland but that pensions should stay within the remit of the UK Government. The report admitted that there was a case for devolving housing benefit and attendance allowance as well as conferring the Scottish Parliament the power of supplementing benefits legislated for at UK level. Although those proposals for further devolution are rather timid they do represent a revolution for the Scottish Conservative party as it finally came to terms with devolution and even committed itself to participating in a Scottish National Convention to consider Scotland's constitutional future in the event of a no vote, a project suggested by Labour MP Douglas Alexander.

If both Labour and the Conservatives shared the similar goal of maintaining the Union and ensuring that there would be limited change to the status quo, the Liberal Democrats stood as the odd ones out in the Better Together partnership. The commission set up by new Scottish leader Willie Rennie and chaired by former leader Menzies Campbell was to define the Liberal Democrats' position on the referendum. It reported in 2012 and argued for a radical decentralisation of tax and borrowing powers to the Scottish parliament, allowing it to raise two thirds of its revenue. It furthermore reaffirmed the principle according to which Liberal Democrats were federalists and that a "rejection of independence will enable Scotland to continue down the track towards a modern, pluralist and federal relationship with the other parts of the United Kingdom". ${ }^{18}$ In defending federalist ideals and proposing Home Rule for Scotland, the Liberal Democrats were trying to appeal to both supporters of independence and of the Union. This broad church message however, was rather absent in the debate due to two factors. The first 
was the awkward position of the Liberal Democrats in Scotland. As partners in the coalition, they were potentially able to influence policy and the Liberal Democrat Secretary of State for Scotland, Michael Moore, gave them a strong voice in the referendum campaign. This position of strength, though, was adversely affected by the unpopularity of their association with the Conservatives in Government and the subsequent loss of support they had suffered in Scotland in the last Scottish Parliament election. The second was linked to individual party interests and the inherent tensions within the Better Together campaign. Indeed, although the three parties involved in the Better Together campaign were working towards the same short-term goal, their longterm objectives in an electoral perspective or even, as we have pointed out, in a constitutional perspective diverged considerably. Liberal Democrat activists found it difficult to combine with Labour activists in constituencies which they would seek to recapture or to keep at the next general election. The forthcoming British and Scottish elections meant that the partners of the Better Together campaign often held their electoral interests higher than the message they were meant to deliver.

\section{A fragmented message}

When Alistair Darling launched the Better Together campaign in June 2012, he stressed that "those of us who believe that it is best for Scotland to be part of the UK - from whatever political views - have a duty now to work in harmony to argue for the better, stronger choice". ${ }^{19}$ Yet, this was wishful thinking as the campaign was inevitably dragged down by internal tensions and divisions. We have seen that, crucially, the three partners did not share the same vision of post-referendum Scotland and would therefore struggle to make a positive case for the Union and deliver an inspiring message. In fact, the individual initiatives of the parties fragmented the pro-Union message. The campaign became less cohesive. Not only did Labour launch its own initiative, United with Labour, in a bid to distance itself from the Conservative and Liberal Democrat coalition partners and in particular with the so-called "bedroom tax", but some Labour figures such as Jim Murphy MP went as far as refusing to share a platform with the Prime Minister. Both leaders of Better Together, Alistair Darling, and United with Labour, Gordon Brown, were not known to be on particularly friendly terms and the creation of the Better Together campaign with no prior consultation of the Labour Scottish Executive inevitably created more tensions within a party already rife with personal disagreements, traditional divisions and disputes. Labour's collaboration with the Coalition Government partners was an easy target for the SNP, which could present the umbrella campaign as a Conservative-led initiative which gathered three British rather than Scottish parties which generally defended austerity policies and welfare cuts. The defence strategy adopted by the three uneasy partners was to shield behind negative economic analyses and experts' assessments aiming at contradicting the SNP's own statistics - which the Coalition Government partners in London provided in abundance by coordinating a series of Scotland Analysis papers presenting the benefits of the Union for Scotland ${ }^{20}$ - and attack the trustworthiness of the SNP project.

17 Given the position of the Better Together campaign as the defender of the status quo, it had trouble departing from what could generally be considered a negative stance. As the challenger, the SNP was able to lead a much more inspiring campaign and deliver a positive message about the future of an independent Scotland. Inevitably, criticism 
formed the core of the No campaign as it sought to attack the reality of the SNP's project. The campaign, which had rebranded itself Project Fear after deciding to base its message on the economic risks presented by independence to appeal to undecided voters, was soon - and sometimes rightly so - accused of scaremongering. ${ }^{21}$ The nickname given to the campaign by its own activists was consequently largely exploited by the Yes camp. Indeed, some stories about Scots facing mobile phone roaming charges, wealthy Scots and business owners fleeing the country overnight after a Yes vote or Lord Robertson's warnings of the "cataclysmic" effect on European and global stability with the risk of "emboldening dictators and annexers around the world" 22 gave credence to accusations of scaremongering. Former Labour First Minister Henry McLeish even advised his party to leave the campaign as he sarcastically remarked: "Next they'll be saying there will be seven years of famine in an independent Scotland and that aliens will land here". ${ }^{23}$ This led Labour chief strategist Douglas Alexander, drafted into the Better Together campaign in its final months, to introduce the idea of a more positive-sounding message with the No Thanks slogan that was inspired by Canadian former Prime Minister Pierre Trudeau's final speech in the 1995 Quebec referendum campaign. ${ }^{24}$

The core of Better Together's criticism however was based on alarming economic analyses as campaigners strove to stress that the Scottish economy was inextricably associated with the UK economy and that turning Scotland's biggest market into its biggest competitor would be damaging to Scotland. Scots, it warned, would subsequently be worse off in an independent Scotland. The campaign raised the spectre of recession, higher taxation, a freeze on public spending and subsequent cuts in public sector jobs, cuts in old-age pensions and public services. It especially stressed the currency issue as Alex Salmond's promise of a currency union with the rest of the UK was undermined by the British parties' stubborn refusal to even consider it a possibility. The Better Together campaign made much of the negative impact of the European currency union, arguing that the rest of the UK would refuse to enter a currency union with a potentially unstable economic partner. The famous Plan B question to Alex Salmond became a leitmotiv to the No campaign and certainly gave Alistair Darling an edge over Salmond during the first televised debate of the official campaign. Other arguments came to feed this discourse as the amount of oil reserves were questioned as well as the unpredictability of oil prices, so was the process for EU membership application for an independent Scotland, the risks of being imposed the euro and the Schengen area if there was a new application process, the end of the European rebate, etc.

19 There was in fact little to inspire voters throughout the No campaign but the goal was to raise anxiety and distrust about the SNP project and dampen the enthusiasm that the Yes campaign might stir in the electorate by opposing facts and figures, experts' opinions and analyses which contradicted those brought forward by the Scottish Government. The expertise brought by both camps on a series of subjects meant that the economics of a future independent Scotland could be read both ways and that there was little to help voters decide whether one expert was right over another. However, the No campaign drew its strength from the fact that anxiety and uncertainty can be potent factors in determining a vote and much was thus made of the idea of independence being a leap in the dark. If the overall tone of the No campaign was indeed negative, its moment of grace came from an unlikely source when former Prime Minister Gordon Brown gave an inspired speech one day before the referendum in which he finally breathed life into the No campaign and was able to combine a passionately patriotic Scottish sentiment with 
the Union. It is doubtful whether the No campaign's last minute moment of grace was sufficient to win the referendum but it did finally mean that there was more to the union than the economic analyses that it had presented all along. It suggested that there was another way of feeling Scottish and having Scotland's best interests at heart, one that had been absent from the campaign all along but which a small majority of Scots expressed on $18^{\text {th }}$ September 2014.

The spirit of unity expressed by Brown's speech would, however, be lacking both in the response to the referendum results by the unionist parties involved in the Better Together campaign as much as in the Labour Party itself, whose Scottish leader Johann Lamont would resign on $24^{\text {th }}$ October 2014 citing the lack of autonomy of the Scottish Labour Party which she felt was treated like a "branch office of London" by the Labour leadership. ${ }^{25}$ After Johann Lamont's resignation, it appeared less likely that the Labour Party, which seemingly refused to give any autonomy to its Scottish leadership, would decentralise further powers to Holyrood if it were to be elected at the general election of May 2015. Indeed, a YouGov poll for the Times published on $3^{\text {rd }}$ February 2015 found that a mere $15 \%$ of all Scots, and $52 \%$ only among Labour voters, said Miliband's party could best use its influence to secure more powers to the Scottish Parliament. It is noteworthy however that $64 \%$ of respondents felt that the SNP would be most likely to deliver further powers to Holyrood. Both the idea that a Labour government is unlikely to deliver more powers to the Scottish Parliament and the proximity between Labour and the Conservative Party during the independence referendum campaign are therefore potent factors in the current electoral trend in Scotland of a sweeping swing to the SNP at the next general election. ${ }^{26}$ It is furthermore questionable whether the election of Jim Murphy as the new Scottish Labour Party leader will help Labour to save its Scottish seats. Not only is Jim Murphy seen as a close figure to Westminster politics due to his years as Minister of State for Europe and Secretary of State for Scotland under the Brown government, but his bid to lead his electoral campaign on a "Vote SNP, get the Tories" slogan may prove to be self-defeating after Labour and the Conservatives were seen to share the same political platform during the referendum campaign.

21 In reality, the three major partners of the Better Together campaign - and signatories of a last-minute joint statement ${ }^{27}$ to transfer significant more powers to the Scottish Parliament in a bid to save the Union after a series of polls showed the Yes vote ahead shared little in common regarding their management of the aftermath of the independence referendum in Scotland. In his speech following the announcement of the referendum results, Conservative Prime Minister David Cameron determined that he would balance the promise of further devolved powers to the Scottish Parliament with the question of "English votes on English laws". Although the move was made in order to outplay both the Ukip and Labour parties in England before the general election of May 2015, the idea that the pledge to devolve more powers to Holyrood would be made contingent upon English-only votes at Westminster was akin to "trying to snatch defeat from the jaws of victory" according to Liberal Democrat Chief Secretary of the Treasury and leading Better Together strategist Danny Alexander. ${ }^{28}$ In the early hours of $19^{\text {th }}$ September, Alistair Darling himself warned the Prime Minister that it would immediately allow the SNP to turn the focus to the future, use the momentum created by the referendum campaign to demand more powers for the Scottish Parliament and present new grievances over English-only votes at Westminster. Significantly, Alex Salmond assured in his resignation speech on the same day that the "dream will never die" as he 
handed the leadership of the SNP to his Deputy First Minister Nicola Sturgeon, thus signalling that the referendum page was turned but a new battle was beginning. It remains to be seen whether the SNP will be able to confirm its lead and snatch a majority of Scottish seats at the general election of May 2015 to deliver upon the promises of a more powerful Scottish Parliament and to establish the kind of Scottish society which would respond to the wishes of nationalists and unionists alike and whose shape emerged more clearly during the independence referendum campaign.

BARNES, E "Independence: Brown Urges Scots not to Give up on UK". Scotland on Sunday, $12^{\text {th }}$ May 2013.BROOKS, L. "Johann Lamont Resigns as Leader of Scottish Labour Party". Guardian, $25^{\text {th }}$ October 2014. CARRELL, S. "Scottish Independence would Weaken UK's Global Status, Says Ex-Nato Chief”. Guardian, $8^{\text {th }}$ April 2014.CARRELL, S., WATT, N. \& WINTOUR, P. "The Real Story of the Scottish Referendum: Britain on the Brink". Guardian, $15^{\text {th }}$ December 2014.CARRELL, S., WATT, N. \& WINTOUR, P. "The Real Story of the Scottish Referendum: the Final Days of the Fight for Independence". Guardian, $16^{\text {th }}$ December 2014. GARDHAM, M. "Yes Campaign to Unveil List of Donors Amid Cash Row". Herald, $8^{\text {th }}$ April 2013.GREEN, C. "Scottish Independence: BBC Scotland's Referendum Coverage 'Institutionally Biased', Alex Salmond Claims". Independent, 14 ${ }^{\text {th }}$ September 2014. PLUNKETT, J. "BBC's Scottish Independence Coverage Accused of Pro-Union Bias". Guardian, $2^{\text {nd }}$ June 2014.The Economist, "Aye'll be back, Comparing Scotland's campaigns". $16^{\text {th }}$ August 2014.WHITAKER, A. "Scottish Independence: Ditch No Campaign - McLeish". Scotsman, $8^{\text {th }}$ July 2013. Official publications presenting the benefits of the Union: https://www.gov.uk/ government/collections/scotland-analysis

February 2015 Scotland general election poll: http://lordashcroftpolls.com/2015/02/ scottish-battleground/ 
Study on social media use during the 2014 Scottish referendum campaign: SHEPARD, M. \& QUINLAN, S. Tipping point online, tripping point offline? University of Strathclyde, March 2014:

http://www.discoversociety.org/2014/04/01/tipping-point-online-tripping-pointoffline/

Unison 2014 Scottish referendum policy: http://www.unison-scotland.org.uk/ scotlandsfuture/referendumpolicy.html

Unite 2014 Scottish referendum policy: http://www.unitetheunion.org/news/unite-willnot-endorse-better-together-or-yes-scotland-for-referendum-run-in/

\section{NOTES}

1. The Economist, “Aye'll be back, Comparing Scotland's campaigns”, $16^{\text {th }}$ August 2014.

2. Kevin ADAMSON \& Peter LYNCH, "The Scottish National Party and the 2014 Independence Referendum", in Kevin ADAMSON \& Peter LYNCH (eds.), Scottish Political parties and the 2014 Independence Referendum, Cardiff: Welsh Academic Press, 2014, p. 43.

3. Mark SHEPARD \& Stephen QUINLAN, Tipping Point Online, Tripping Point Offline?, University of Strathclyde, March 2014, http://www.discoversociety.org/2014/04/01/tipping-point-onlinetripping-point-offline/

4. Ibid.

5. John PLUNKETT, “BBC's Scottish Independence Coverage Accused of Pro-Union Bias", Guardian, $2^{\text {nd }}$ June 2014; Chris GREEN, "Scottish Independence: BBC Scotland's Referendum Coverage 'Institutionally Biased', Alex Salmond Claims", Independent, 14 $4^{\text {th }}$ September 2014.

6. Magnus GARDHAM, "Yes Campaign To Unveil List Of Donors Amid Cash Row", Herald, $8^{\text {th }}$ April 2013.

7. http://www.unison-scotland.org.uk/scotlandsfuture/referendumpolicy.html

8. http://www.unitetheunion.org/news/unite-will-not-endorse-better-together-or-yes-scotlandfor-referendum-run-in/

9. Scottish Organiser (Bargaining and Campaigns) at Unison Scotland.

10. Eddie BARNES, “Independence: Brown Urges Scots not to Give up on UK", Scotland on Sunday, $12^{\text {th }}$ May 2013.

11. Eric SHAW, The Scottish Labour Party and the 2014 Independence Referendum in Kevin ADAMSON \& Peter LYNCH (eds.), Scottish Political Parties and the 2014 Independence Referendum, Cardiff: Welsh Academic Press, 2014, p. 68.

12. SCOTTISH LABOUR DEVOLUTION COMMISSION, Powers for a Purpose - Strengthening Accountability and Empowering People, March 2014, p. 11.

13. Murdo Fraser speech, $5^{\text {th }}$ September 2011, "Murdo Fraser reveals plans for new Scottish Tory party", online video: http://www.telegraph.co.uk/news/uknews/scotland/scottishpolitics/8742143/Murdo-Fraser-reveals-plans-for-new-Scottish-Tory-party.html

14. Ruth Davidson speech, "Winning for Scotland", 9th September 2011, online video : https:// www.youtube.com/watch?v=99r68XFpMDU

15. David Cameron, "Scotland Speech", 16th February 2012, https://www.gov.uk/government/ speeches/transcript-pm-scotland-speech 
16. Ruth Davidson, "Strengthening Scotland", Taking Scotland Forward speech, 26th March 2013, http://www.scottishconservatives.com/2013/03/strengthening-devolution-taking-scotlandforward/

17. SCOTTISH CONSERVATIVES, Commission on the Future Governance of Scotland, May 2014.

18. SCOTTISH LIBERAL DEMOCRATS, Federalism: The Best Future for Scotland, Report of the Home Rule and Community Commission of the Scottish Liberal Democrats, October 2012, p. 19.

19. Alistair Darling, "Better Together Launch" speech, 25 th June 2012, https:// secure.bettertogether.net/press/entry/full-transcript-of-the-launch-event-speech-by-alistairdarling

20. https://www.gov.uk/government/collections/scotland-analysis

21. Severin CARRELL, Nicholas WATT \& Patrick WINTOUR, "The Real Story of The Scottish Referendum: Britain On The Brink", Guardian, 15 ${ }^{\text {th }}$ December 2014.

22. Severin CARRELL, “Scottish Independence Would Weaken UK's Global Status, Says Ex-Nato Chief", Guardian, $8^{\text {th }}$ April 2014.

23. Andrew WHITAKER, "Scottish Independence: Ditch No Campaign - McLeish", Scotsman, $8^{\text {th }}$ July 2013.

24. Severin CARRELL, Nicholas WATT \& Patrick WINTOUR, "The Real Story of The Scottish Referendum: The Final Days of The Fight For Independence", Guardian, $16^{\text {th }}$ December 2014.

25. Libby BROOKS, "Johann Lamont Resigns as Leader of Scottish Labour Party", Guardian, $25^{\text {th }}$ October 2014.

26. According to Lord Ashcroft's poll published on $4^{\text {th }}$ February 2015, the SNP could win 54 out of 59 seats in Scotland in May 2015 with an overall swing to the SNP of $25.4 \%$ in Labour-held constituencies. http://lordashcroftpolls.com/2015/02/scottish-battleground/

27. The Vow was published in the Daily Record of $15^{\text {th }}$ September 2014 and signed by David Cameron, Ed Miliband and Nick Clegg. It pledged to transfer "extensive" new powers to the Scottish Parliament and protect the NHS. "The Scottish Parliament is permanent and extensive new powers for the Parliament will be delivered by the process and to the timetable agreed and announced by our three parties, starting on $19^{\text {th }}$ September [...] And because of the continuation of the Barnett allocation for resources, and the powers of the Parliament to raise revenue, we can state categorically that the final say on how much is spent on the NHS will be a matter for the Scottish Parliament. We believe that the arguments that so powerfully make the case for staying together in the UK should underpin our future as a country. We will honour those principles and values not only before the referendum but after. People want to see change. A No vote will deliver faster, better and safer change than separation". Scottish Labour leader Jim Murphy and former Prime Minister Gordon Brown have presented a renewed commitment to the Vow - in a move dubbed the Vow Plus by political commentators - on $2^{\text {nd }}$ February 2015, unveiling Labour plans for further devolution of welfare powers to Scotland.

28. Severin CARRELL, Nicholas WATT \& Patrick WINTOUR, "The Real Story of the Scottish Referendum: Britain on the Brink", Guardian, 15 $5^{\text {th }}$ December 2014.

\section{ABSTRACTS}

Better Together was the main umbrella organisation of the No camp during the 2014 Scottish independence referendum campaign. It represented the common effort of three otherwise 
unlikely-minded British parties to work together and publicly collaborate to safeguard the Union. The difficulties that this collaboration represents were immense in that the three participating parties had distinct electoral and political histories in Scotland and each faced inner divisions and distinct challenges which this paper seeks to examine.

Better Together fut la principale organisation multi-partite à œuvrer pour un vote «non » lors de la campagne pour le référendum sur l'indépendance écossaise de 2014. Elle représente les efforts communs de trois partis politiques très différents au plan idéologique pour travailler de concert afin de sauvegarder l'Union britannique. Les difficultés que cette collaboration a soulevées furent immenses: ces trois partis sont héritiers de traditions politiques et d'histoires électorales distinctes en Écosse, et chacun d'entre eux dut faire face à des divisions internes et à des défis distincts que cet article se propose de mettre en lumière.

INDEX

Keywords: Scottish independence referendum, Better Together, Scottish political parties, Scottish politics, British politics

Mots-clés: Better Together, partis politiques écossais, politique écossaise, politique britannique

\section{AUTHOR}

FIONA SIMPKINS

Université de Lyon 2 - Lumière 